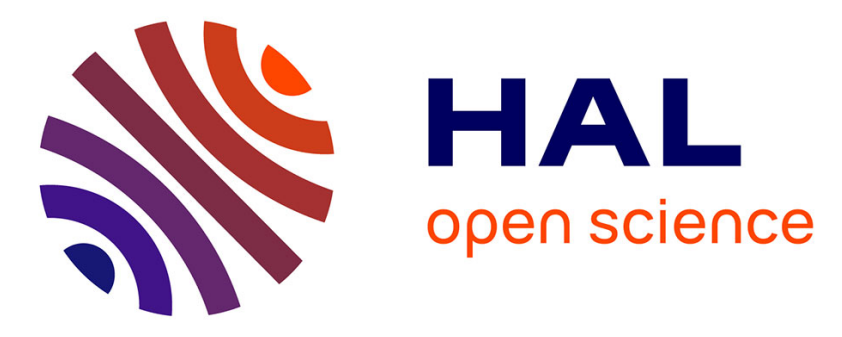

\title{
Bacteria associated with early life stages of the great scallop, Pecten maximus: impact on larval survival
}

Lise Torkildsen, Christophe Lambert, Are Nylund, Thorolf Magnesen, Øivind Bergh

\section{- To cite this version:}

Lise Torkildsen, Christophe Lambert, Are Nylund, Thorolf Magnesen, Øivind Bergh. Bacteria associated with early life stages of the great scallop, Pecten maximus: impact on larval survival. Aquaculture International, 2005, 13 (6), pp.575-592. 10.1007/s10499-005-9002-5 . hal-00590935

\section{HAL Id: hal-00590935 https://hal.science/hal-00590935}

Submitted on 5 May 2011

HAL is a multi-disciplinary open access archive for the deposit and dissemination of scientific research documents, whether they are published or not. The documents may come from teaching and research institutions in France or abroad, or from public or private research centers.
L'archive ouverte pluridisciplinaire HAL, est destinée au dépôt et à la diffusion de documents scientifiques de niveau recherche, publiés ou non, émanant des établissements d'enseignement et de recherche français ou étrangers, des laboratoires publics ou privés. 


\title{
Bacteria associated with early life stages of the great scallop, Pecten maximus: impact on larval survival
}

\author{
LISE TORKILDSEN 1 CHRISTOPHE LAMBERT 1,2 ARE NYLUND 3 \\ THOROLF MAGNESEN 4 and ØIVIND BERGH $1,{ }^{*}$
}

\author{
1 :Institute of Marine Research, P.O. Box 1870 NordnesN-5817, Bergen, Norway; \\ 2 :Laboratoire des sciences de l'environnement marin (LEMAR), Institut Universitaire Europe'en de la Mer (IUEM), Université de \\ Bretagne Occidentale (UBO), Place Copernic, technopole Brest-Iroise, 29280, Plouzané, France; \\ 3 :Department of Biology, University of Bergen, Thormøhlens gt. 55, N-5008, Bergen, Norway; \\ 4 :University of Bergen, Centre for Studies of Environment and Resources, P.O. Box 7800N-5020, Bergen, Norway;
}

*Author for correspondence (e-mail: oivind.bergh@imr.no.; phone: +47-55236370; fax: +47-55236379)

Key words: Bacteria, Challenge experiment, Phenotypic characterisation, 16S rDNA, Scallop Larvae.

\begin{abstract}
A bacteriological study was carried out at a scallop (Pecten maximus) hatchery near Bergen, western Norway following a severe increase in mortality rates during the larval stages of the scallops. No larvae survived to settling, except for those in groups treated prophylactically with chloramphenicol. In order to identify pathogenic strains of bacteria, we performed a challenge test on 10- to 16-day-old larvae using isolated bacterial strains from the hatchery. Infection with six of these strains produced mortalities that were not statistically different from that resulting from infection with the known pathogen Vibrio pectenicida. However, about $5 \%$ of the strains tested in the challenge experiment produced higher motility rates than found in the unchallenged control group, indicating a possible probiotic effect. On the basis of 16S rDNA analysis on these strains, the phylogenetic tree indicated two groups of apparent pathogens: (1) one strain, LT13, grouped together with Alteromonas/Pseudoalteromonas; (2) a cluster of strains grouped together with Vibrio splendidus (LT06, LT21, LT73, PMV18 and PMV19). Strain LT13 was isolated from cultures of the microalga Chaetoceros calcitrans used for feed, while the other strains were isolated from larval cultures. Transmission electron microscopy showed intracellular bacteria that resembled bacteria in the groups Chlamydiaceae and Rickettsiaceae.
\end{abstract}

\section{Introduction}

Many countries worldwide are currently expending considerable effort and resources towards the establishment of a sustainable production of spat of various marine species for use in aquaculture. Among the species being investigated, the great scallop, Pecten maximus, is attracting much interest due to its natural occurrence in Norwegian waters, its high market price and the existence of established markets in other countries (reviewed by Bergh and Strand 2001).

The stable production of sufficient spat is crucial to the establishment of a scallop industry. Scallop spat is currently produced commercially at one hatchery in Norway (Scalpro A/S), located at Rong in the County of Hordaland. A research facility is also operational at the Austevoll Research Station of the Institute of Marine Research, also situated in Hordaland county. Like all marine organisms, shellfish live in an ecosystem that contains large numbers of bacteria, among which opportunist species may be frequent. Bacterial diseases in bivalves occur mainly during the larval stages. As early as 1965, Tubiash et al. (1965) demonstrated bacterial necrosis in mollusc larvae from the United States, and subsequent investigators have reported that bacterial diseases can severely limit bivalve larval production (Elston and Leibovitz 1980; Nicolas et al. 1992, 1996; Riquelme et al. 1995a). The early life stages of bivalves are typically susceptible to bacterial pathogens that apparently do not affect post-larval stages if precautions are taken (Nicolas et al. 1996). However, the identification of causative agents of epizootics at the early life stages of aquatic organisms has been hampered by a lack of challenge protocols for fish and invertebrate larvae. Several recent studies have addressed this problem, and protocols have been developed for challenge tests that are capable of verifying the pathogenicity of bacterial causative agents of disease in fish and bivalve larvae (Bergh et al. 1992; Riquelme et al. 1995a; Lambert et al. 1998; Sugumar et al. 1998). Culturable bacteria that result in the mortality of shellfish larvae have been assigned to four genera: Pseudomonas (Brown 1974), Alteromonas (Garland et al. 1983), Aeromonas (Riquelme et al. 1996a) and Vibrio (Nicolas et al. 1992; Riquelme et al. 1995b, Sugumar et al. 1998; Torkildsen et al. 2000). In many cases, the causative agents have only been identified to the genus level. Vibrio appears to be the genus most frequently involved in bacterial mortality of shellfish larvae. A Vibrio anguillarum-related strain pathogenic to the Chilean scallop, Argopecten purpuratus, has been identified (Riquelme et al. 1995a), while Vibrio pectenicida has been isolated and described by Lambert et al. (1998) as being the major cause of mortality during the production of $P$. maximus larvae in France. We report here our investigation of the 
bacteria associated with $P$. maximus larvae in which we employed a challenge test to identify both pathogenic and possible beneficial strains.

\section{Materials and methods \\ Source of scallop eggs and larvae}

All egg groups were collected from a commercial scallop hatchery, Scalpro A/S, Rong, near Bergen, Norway. The broodstock originating from Hordaland County was conditioned in the hatchery following standard operating procedures. The eggs were collected in March and April 1997, and from March to June 1999. Samples were taken from eggs and from larvae 3, 10, 13 and 17 days after fertilisation. Spawning was induced by thermal shock. Eggs were fertilised following the method described by Gruffyd and Beaumont (1970). After fertilisation, the embryos were allocated to two tanks (800 I) containing seawater obtained from the nearby fjord at a depth of $60 \mathrm{~m}$ and filtered through a $1-1 \mathrm{~m}$ bag filter; the embryos were kept in the stagnant seawater at $18 \pm 1^{\circ} \mathrm{C}$. The seawater in the tanks was replaced three times a week with fresh seawater from the fjord. In order to compare the survival of larvae in the experimental groups with that of the untreated groups, the larvae in one of the tanks were treated prophylactically with chloramphenicol $\left(10 \mathrm{mg} \mathrm{L}^{-1}\right)$. The first treatment was given 3 days after spawning, and then at every renewal of water. The larvae were fed monocultures of the algae Isochrysis galbana (Parke) Tahitian strain, Pavlova lutheri (Droop) and Chaetoceros calcitrans (Takano) in a 1:1:2 ration to a total concentration of 50 cells $L^{-1}$.

Isolation of bacteria

Bacterial strains were sampled in triplicate fromfertilised eggs, fromlarvae treated with chloramphenicol and from untreated larvae. Each sample was counted using a dissection microscope and consisted of approximately 100,000 eggs and between 50,000 and 100,000 larvae. The eggs and larvae were washed three times in autoclaved seawater at a $25 \%$ salinity (SSW) prior to homogenisation in $10 \mathrm{ml} \mathrm{SSW}$. Dilution series were made using $25 \%$. SSW plated out on petri dishes containing Difco 2216 Marine Agar (MA) (Difco, Detroit, Mich.), Tryptone Citrate Bile Sucrose agar (TCBS) (Oxoid, Basingstoke, UK) and Tryptone Soy Agar (TSA) (Oxoid). Following aerobic incubation for 3 days at $18{ }^{\circ} \mathrm{C}$, representative colonies (120) were selected for further characterisation. Some of the bacterial strains were isolated from algal cultures used as feed for the larvae.

\section{Challenge test}

Of the strains isolated as described above, about 100 were tested using a bath challenge test. Larvae were sampled from chloramphenicol-treated cultures at the hatchery between 10 days and 16 days after spawning and placed in a 24-well plate, at 20_30 larvae per well, in $2 \mathrm{ml} \mathrm{SSW}$. This was followed by the addition to each well of $100 \mu \mathrm{l}$ of a 24-h bacterial culture that had been washed twice in SSW. Twelve replicates of each strain were made. Inoculations were repeated with 10-fold and 100-fold dilutions of the bacterial culture $\left(\begin{array}{ll}5 & 105 \\ \text { cells L }^{-1_{1}}\end{array}\right)$. One 24 -well plate without bacterial addition was used as the control. The strain A496 of Vibrio pectenicida was used as a positive control. The plates were incubated at $16{ }^{\circ} \mathrm{C}$ in an air-conditioned room. Afte $\mathrm{r} 48 \mathrm{~h}$, the number of dead larvae was determined by counting (with a Leitz DM IL inverted stereoscopic microscope) the number of non-swimming larvae lying on the bottom with closed valves (dead larvae plus non-active larvae). This count was made for at least six wells for each bacteria strain and for each bacterial dilution. Wells with fewer than ten larvae were discarded. The results for each bacterial strain in the challenge test were compared with the positive control using a chi-square goodness-of-fit with $p=0.05$.

\section{Biochemical tests}

All strains were Gram-stained (Merck, Germany). Biochemical tests were performed using API 20E (BioMerieux, France). In addition, the following tests were carried out at $18{ }^{\circ} \mathrm{C}$ according to the method described by Hansen and Sørheim (1991): oxidative/fermentative metabolism of glucose, aerobic acid production from fructose, sucrose, mannitol, mannose, glycerol, ribose and $\mathrm{N}$-acetylglucosamine, gelatinase, nitrate reductase, Voges-Proskauer, methyl red, production of indole from trytophan, and degradation of Tween 80 . The citrate test was carried out with $2 \% \mathrm{NaCl}$ added to Simmon's citrate medium. The strains were tested for growth on TCBS; the oxidative carbohydrate tests were incubated for 5 days, the fermentative glucose test for 7 days and the indole, VogesProskauer, methyl red, nitrate reductase and TCBS tests for 14 days, while the citrate tests were incubated for 4 weeks. Polymerase chain reaction amplification of 16S rDNA genes Each bacterial strain (102 strains in total) was grown to visible growth $(24-48 \mathrm{~h})$ at $18{ }^{\mathrm{C}} \mathrm{C}$. The bacteria $(1 \mathrm{ml})$ were harvested by centrifugation $(16,060 \mathrm{~g})$, washed twice with $0.9 \% \mathrm{NaCl}$ and resuspended in $100 \mu \mathrm{l}$ 
distilled $\mathrm{H}_{2} \mathrm{O}$. Universal eubacterial primers were used (27f and $1492 \mathrm{r}$, Escherichia coli numbering). The PCR was performed in reaction mixtures of $50 \mu$ l containing $0.025 \mathrm{U}$ Taq DNA polymerase (Promega, Madison, Wis.), $200 \mu \mathrm{M}$ of each of the four dNTPs (Promega), $0.1 \mu \mathrm{M}$ of each primer and $2.5 \mathrm{mM}$ of $\mathrm{MgCl}_{2}$. In addition, $1 \mathrm{ll}$ of the bacterial sample was added. Distilled water was used as control for contamination, and Vibrio anguillarum was used as a positive control. PCR amplification was performed in an automated thermal cycler (Gene Amp, PCR system 9700; Perkin Elmer, Foster City, Calif.) with an initial denaturation at $94^{\circ} \mathrm{C}$ for $5 \mathrm{~min}, 30$ cycles of denaturation ( 1 min at $94{ }^{\circ} \mathrm{C}$ ), annealing $\left(30 \mathrm{~s}\right.$ at $60^{\circ} \mathrm{C}$ ) extension $\left(3 \mathrm{~min}\right.$ at $72^{\circ} \mathrm{C}$ ) and a final extension at $72{ }^{\circ} \mathrm{C}$ for $10 \mathrm{~min}$. Amplified DNA (5- $\mu$ l aliquots) was examined by horizontal electrophoresis on a $1 \%$ agarose gel (Promega).

\section{Amplified rDNA restriction analysis (ARDRA)}

ARDRA was performed as described by Vaneechoutte et al. (1992) and Jensen et al. (2002). Restriction was carried out overnight (minimum of $6 \mathrm{~h}$ ) at $37^{\circ} \mathrm{C}$ in $25 \mu \mathrm{l}$ of incubation buffer (Promega) containing $4 \mathrm{U}$ of a restriction endonuclease - Cfol (GCGC), Hinfl (GANTC) or Alul (AGCT) (Promega) - and $10 \mu \mathrm{l}$ of PCR product. Restricted DNA was analysed by horizontal electrophoresis on a $2.5 \%$ Methaphor gel (FCM BioProducts, Rockland, Maine) in an electric field of $6.5 \mathrm{~V} \mathrm{~cm}{ }^{-1}$. Gels were stained with ethidium bromide $\left(1 \mathrm{lg} \mathrm{ml}^{-1}\right)$ for $1 \mathrm{~h}$ and then photographed (Polaroid type Polapan Pro 100 films). Differences in restriction fragment patterns indicated differences in DNA sequences. Photos were scanned and banding patterns aligned into groups for each enzyme using the software GelCompar 3.1 (GelCompar, Kortrijk, Belgium). For analysis, patterns were coded as 0 (band absence) or 1 (band present). The results were used in a phylogenetic analysis using the PHYLIP software package (Felsenstein 1993).

\section{Sequencing of $16 \mathrm{~S}$ rDNA}

Of those bacterial strains found to cause mortality to the scallop larvae, those whose 16S rDNA was determined not to be different from that of Vibrio pectenicida in the challenge test were sequenced. The PCR product was purified using a Concert PCR Purification System (Life Technologies GibcoBRL, UK) and subsequently stored at ) $20^{\circ} \mathrm{C}$. The sequenc ing reactions were performed according to a protocol from Perkin Elmer with some modifications. A reaction mixture of $10 \mu \mathrm{l}$ was used: $4 \mathrm{ll} \mathrm{BIG}$ DYE-Terminator Ready Reaction Mix (Perkin Elmer), $4 \mu \mathrm{l}$ template and $2 \mu \mathrm{l}$ general eubacterial primer (27f, 530f, 926f, 685r, 1100r and 1492r; E. coli numbering). The reaction was performed in a GeneAmp PCR system 9700 , with 25 cycles of $96{ }^{\circ} \mathrm{C}$ for $10 \mathrm{~s}, 50^{\circ} \mathrm{C}$ for $5 \mathrm{~s}$ and $60^{\circ} \mathrm{C}$ for 4 min. Sequences were obtained using an $\mathrm{ABI} 377$ sequence analyser (Perkin-Elmer Applied Biosystems, Foster City, CA).

\section{Phylogenetic analysis}

The small subunit (SSU) sequences were aligned by eye to alignments of bacterial SSU rRNA sequences obtained from the rRNA website of the Department of Biochemistry, Molecular Biology, University of Antwerp (UIA), Belgium (Van de Peer et al. 2000). These alignments were used in the phylogenetic analysis using the PHYLIP software package (Felsenstein 1993).

\section{Electron microscopy}

Larvae from the different groups were sampled between days 3 and 20 after spawning. The samples were kept at $4{ }^{\circ} \mathrm{C}$, and sparkling mineral water was added for approximately 2 min before the fixative was added. The larvae were fixed in a modified Karnovsky fixative (Karnovsky 1965), in which distilled water was replaced with Ringers solution: $9.0 \mathrm{~g} \mathrm{NaCl}, 0.14 \mathrm{~g} \mathrm{KCl}, 0.12 \mathrm{~g} \mathrm{CaCl}_{2}, 0.2 \mathrm{~g} \mathrm{NaHCO}_{3}, 2.0 \mathrm{~g}$ glucose in $1 \mathrm{I}$ distilled water. Osmolarity was adjusted by adding sucrose up to an osmolarity of $8 \%$. The samples were kept in fixative at $4^{\circ} \mathrm{C}$ for a minimum of $24 \mathrm{~h}$ before being washed in phosphatebuffered Ringers solution $(\mathrm{PbR})$ and treated with $2 \% \mathrm{OsO}_{4}$ for a minimum of $1 \mathrm{~h}$. They were then washed again, decalcified with $1 \%$ ascorbic acid in $15 \mathrm{~N} \mathrm{NaCl}$ for $24 \mathrm{~h}$ and given a final wash (in $\mathrm{PbR}$ ) before being dehydrated through a graded series of acetone and embedded in TAAB 812 Resin. The ultrathin sections were stained in $2 \%$ uranyl acetate for $60 \mathrm{~min}$ and $1 \%$ lead citrate for $5 \mathrm{~min}$.

\section{Results}

Larval survival in the hatchery

In the hatchery, no untreated larvae survived until settling in any of the three batches used in this study. Survival in the three treated groups was calculated to be 3,16 and $19 \%$, respectively. 
Challenge test

The average mortality of the larvae in the unchallenged control groups was $19.4 \%$. Of the 100 bacterial strains tested, larval survival rates were significantly $(p<0.05)$ affected by 71 of them in that they caused increased mortality. The greatest impacts on larval mortality were caused by six strains (LT06, LT13, LT21, LT73, PMV18 and PMV19), which caused mortalities not significantly different from that caused by $V$. pectenicida. The average mortality of the groups challenge with $V$. pectenicida was $67.1 \%$. One of the bacterial strains, LT13, that caused a higher mortality than that observed in the control group was isolated from a culture of the alga Chaetoceros calcitrans. Strain LT47 was also isolated from $C$. calcitrans and was grouped together with LT13 by the ARDRA analysis. In the challenge test, however, strain LT47 did not cause any higher mortality than the control. Apart from strain LT13, the remaining strains were isolated from larvae aged 3 days (LT06), 13 days (LT73) and 21 days (PMV18 and PMV19). These larval batches were not treated with any antibacterial agent. One strain (LT21) was isolated from larvae (10-days-old) treated with chloramphenicol. Five percent of the larval groups, i.e. five bacterial strains in the challenge test, displayed increased motility compared to the control larvae.

Phenotypic characterising

All strains that were isolated were Gram-negative, and all except one were rodshaped. Nearly all of the bacterial strains tested $(92 \%, n=50)$ were sensitive to diagnostic discs containing $150 \mu \mathrm{g} \mathrm{O} / 129$, (Oxoid, Basingstoke, England). Of the strains tested, $56 \%(n=25)$ showed haemolytic properties. None of the strains isolated from eggs could use glucose fermentatively. Significantly (chi-square goodnessof-fit with $p<0.05$ ) more bacterial strains fermented glucose in the untreated larval culture than in the culture treated with chloramphenicol. Phenotypic characterisation of the six strains that produced the same mortality as $V$. pectenicida in the challenge test as determined by API 20E (Table 1) gave a cluster of five strains that were almost identical according to their biochemical profile (LT06, LT21, LT73, PMV18 and PMV19) and one that was different (LT13). These strains differed with respect to the following tests: PMV19 tested negative for arginine dihydrolase, whereas the others were positive; LT06 and LT21 produced H2S; PMV19 was positive for urease; LT73 was negative for VP-acetoine; LT06 and LT21 did produce acid from saccharose; LT21 was negative for nitrite (Table 1). Otherwise, the strains gave identical profiles. 
Table 1. Phenotypic characterisations by API 20E of bacterial strains that result in the same mortality rate as Vibrio pectenicida in a challenge test on scallop larvae.

\begin{tabular}{lcccccc}
\hline & LT06 & LT13 & LT21 & LT73 & PMV18 & PMV19 \\
\hline ONPG $\beta$-galactosidase & + & + & + & + & + & + \\
Arginine dihydrolase & + & - & + & + & + & - \\
Lysine decarboxylase & - & - & - & - & - & - \\
Ornithine decarboxylase & - & - & - & - & - & - \\
Simmon's citrate & + & - & + & + & + & + \\
Production of $\mathrm{H}_{2} \mathrm{~S}$ & + & - & + & - & - & - \\
Urease & - & - & - & - & - & + \\
Tryptophan desaminase & - & - & - & - & - & - \\
Indole & + & - & + & + & + & + \\
VP-Acetoine & + & + & + & - & + & + \\
Gelatine & + & + & + & + & + & + \\
Glucose/O & + & + & + & + & + & + \\
Mannitol & + & + & + & + & + & + \\
Inositol & - & - & - & - & - & - \\
Sorbitol & - & - & - & - & - & - \\
Rhamnose & - & - & - & - & - & - \\
Saccharose & + & + & + & - & - & - \\
Melibiose & - & - & - & - & - & + \\
Amygdaline & + & - & + & + & + & + \\
Arabinose & + & - & - & - & - & + \\
Oxidase & + & + & + & + & + & + \\
Nitrites & + & + & + & + & + & + \\
Catalase & + & + & + & + & + \\
& + & + & + & + & +
\end{tabular}

Phenotypic characterisation by the Hansen and Sørheim (1991) method (Table 2) gave a cluster of four strains (LT06, LT73, PMV18 and PMV19) and one strain (LT21) as a separate group. LT13 was not further characterised by this method. LT21 tested negative for the carbohydrates.

\section{ARDRA}

ARDRA was performed on 102 strains isolated from scallop larvae and algae and on 11 reference strains. The results from the ARDRA were phylogenetically analysed with parsimony, Dollop, and a consensus tree was drawn. The significance of the tree topology was tested by means of bootstrapping. The supports for the branches were in most cases lower than $50 \%$, and the results overall were inconsistent.

Phylogenetic analysis based on 16S rDNA sequencing

We sequenced six strains isolated from scallop larvae and two strains of $V$. anguillarum (01 and 02). The piece of the SSU rDNA that was sequenced varied from 1436 to $1447 \mathrm{bp}$ for the strains isolated from scallop larvae, while it was 1431 for both of the $V$. anguillarum strains. The SSU sequences were aligned with similar bacterial sequences obtained from GenBank (Table 3). This alignment contained 20 bacterial strains, with Vibrio cholerae as an out-group. Most of the differences between the strains lay in regions 6 and 18 according to the secondary structure (Van de Peer et al. 2000). 
Table 2. Phenotypic characterations, using a multidish method (Hansen and Sorheim 1991), of strains that gave the same mortality as Vibrio pectericida in a challenge test on scallop larvae.

\begin{tabular}{lccccc}
\hline & LT06 & LT21 & LT73 & PMV18 & PMV19 \\
\hline$N$-Acetyl-glucosamine & + & - & + & - & + \\
Fructose & - & - & + & + & + \\
Ribose & + & - & - & + & + \\
Saccharose & + & - & + & + & + \\
Mannitol & + & - & + & + & + \\
Mannose & + & - & - & + & + \\
Glycerol & - & - & + & + & + \\
Glucose/O & + & - & + & + & + \\
Glucose/F & + & - & + & + & + \\
Indole & + & - & + & + & + \\
Methylene red & + & - & - & + & + \\
VP-acetoin & - & - & + & + & + \\
Citrate & - & - & - & + & + \\
Nitrite & + & + & + & + & + \\
Tween-80 & + & + & + & + & + \\
Amylase & - & - & + & + & + \\
$\beta$-Galactosidase & - & + & - & + & + \\
\hline
\end{tabular}

Table 3. Bacterial strains used in the phylogenetic analysis.

\begin{tabular}{llll}
\hline Strain & Culture collection & GenBank accession no. & Source \\
\hline Vibrio cholerae & ATCC 14033 & X74694 & GenBank \\
V. fischeri & ATCC 7744T & X74702 & GenBank \\
Pseudoalteromonas & & A B038036 & GenBank \\
Alteromonas elyaovii & & AF082562 & GenBank \\
A. distincta & & AF082564 & GenBank \\
Vibrio splendidus & ATCC 3789 & A B038030 & GenBank \\
V. tapetis & & Y08430 & GenBank \\
V. pectenicida & & Y13830 & GenBank \\
V. vulnificus & & X56582 & GenBank \\
V.parahaemolyticus & & X56580 & GenBank \\
V. alginolyticus & ATCC 17749 & X56576 & GenBank \\
V. tubiadii & ATCC 19109T & X74725 & GenBank \\
V. anguillarum 01 & NCMB 2129 & & \\
V. anguillarum 02 & ATCC 43306 & & Present study \\
LT06 & & & Present study \\
LT13 & & Present study \\
LT21 & & Present study \\
LT73 & & Present study \\
PMV18 & & Present study \\
PMV19 & & &
\end{tabular}

Phylogenetic analyses of the aligned sequences were conducted with parsimony, the distance method (Kimura-2 parameter with neighbour joining) and the maximum likelihood method (ML). The use of parsimony, the distance and ML method produced trees with similar overall topology. The significance of the tree topology was tested by means of bootstrapping (Figure 1). The analysis shows that the strains could be divided into two groups: LT13 grouped with Alteromonas and Pseudoalteromonas in group I; LT06, LT21, LT73, PMV19 and PMV18 grouped with Vibrio splendidus in group II. Vibrio fischeri grouped with either group I or group II according to which method was used:when parsimony and the distance method were used, V. fischeri grouped with group II, and when the ML method was used $V$. fischeri grouped with group I. 
Transmission electron microscopy (TEM)

TEM screening of the early developmental stages of $P$. maximus revealed surprisingly few bacteria in the digestive system. Those that were present in the digestive system were rod-shaped. No further attempt was made to identify these bacteria. Only a few bacteria were found in the tissue of the larvae. These included two different types of intracellular bacteria of the gut epithelium. One type was located within the vacuoles of the host cells, and the nucleus of the host cell appeared to be slightly flattened compared to the uninfected neighbouring cells. The cytoplasm of the infected cells was dominated by mitochondria and membrane accumulations that may be endoplasmatic reticulum.

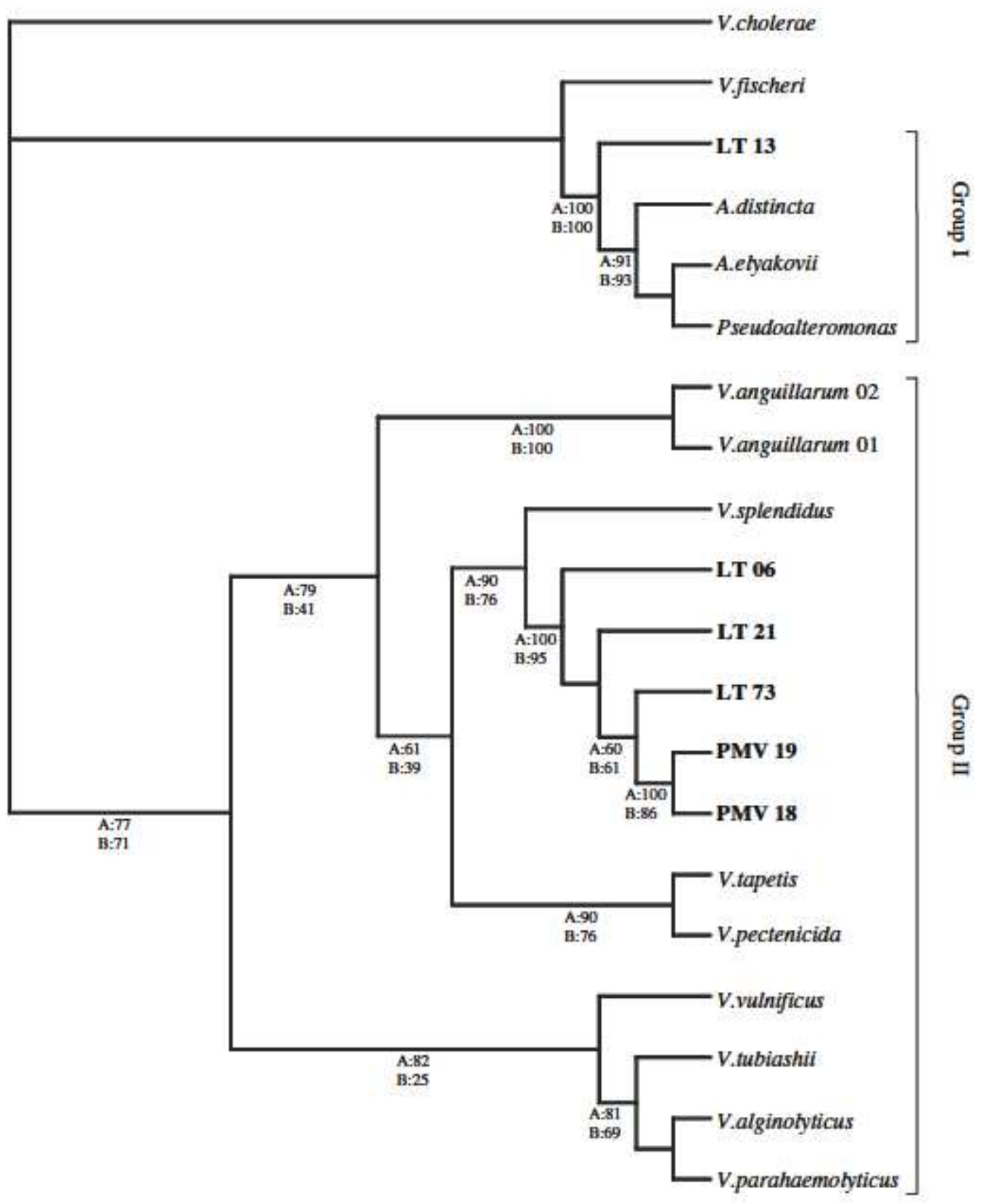

Figure 1. A phylogeny tree was obtained with DNAm1. Numbers on the tree indicate: (a) the percentage of bootstrap replicates (1000 bootstrap replicates) that contained DNAdist topology; (b) the percentages of bootstrap replicates (1000 bootstrap replicates) that contained DNApars topology. Vibrio cholerae was used as an out-group. 


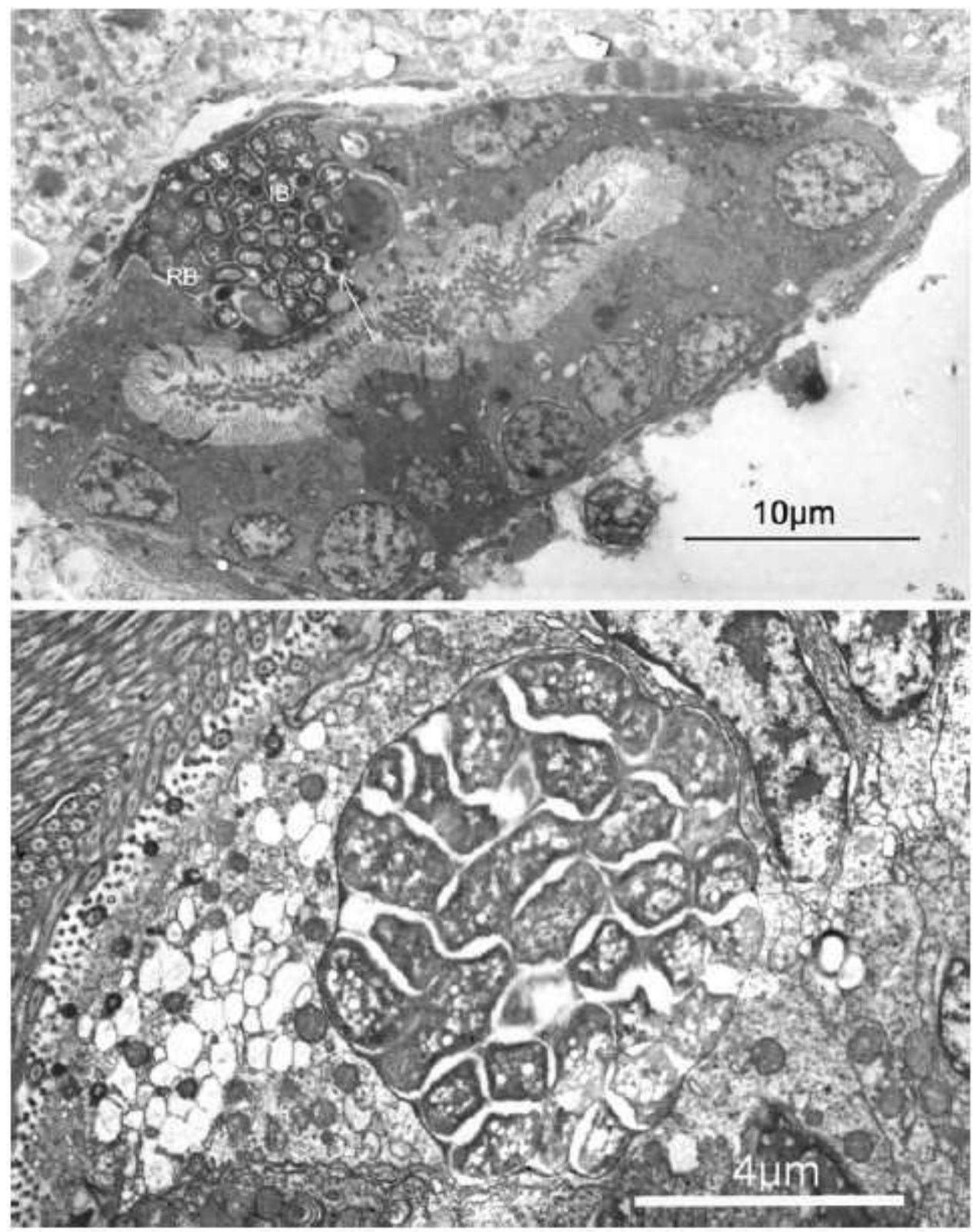

Figure 2. Above: Pleomorphic intracellular bacteria in the gut epithelium of 21-day-old larvae of Pecten maximus. The bacteria contain three different morphologies - large (reticulate bodies, RB), intermediate (IB); condensed (elementary bodies, EB, arrow) bodies - within the same cell. The RB are slightly irregularly shaped and seem to contain homogeneously distributed granular material (ribosomes), while the smaller, elliptical, IB have a vacuolated cytoplasm. The EB are spherical and contain an electron-dense cytoplasm. The bacteria show similarities with intracell ular bacteria from fish with epitheliocystis. Below: Pleomorphic intracellular bacteria in the gut epit helium of 22-dayold larvae of $P$. maximus. The bacteria are intra-vacuolar, elongated, branched and without distinct nuclear aneas. The bactenia show similarities with intracellular, intra-vacuolar bacteria from fish with epitheliocystis.

These appeared to be more electron-lucent than those of the uninfected cells. These bacteria were pleomorphic, had elongated, branching, were at least $5.0 \mu \mathrm{m}$ long (Figure 2, lower) and contained no obvious nuclear areas. The second type was also intracellular, but with two different free stages in the cytoplasm of the gut cells (Figure 2, upper). The host cell cytoplasm was denser than that of the surrounding non-infected cells, which made it easy to locate the infected cells in the gut epithelium of the larvae. The different morphological stages of this bacterium were classified as reticulate bodies (RB) and intermediate bodies (IB). Both morphologies occurred in the same cell. The RBs were 
slightly irregularly shaped, with the largest being at least $2.5 \mu \mathrm{m}$ long. They contained homogeneously distributed granular material, probably ribosomes, and several chromatin strands distributed throughout the cytoplasm. The smaller, elliptical IB, about $1.5 \mu \mathrm{m}$ long and about $1.0 \mu \mathrm{m}$ in diameter, had a centrally vacuolated cytoplasm and seemed to contain one or two chromatin strands. The cytoplasm near the cell membrane was highly electron-dense and seemed to consist of granular material (ribosomes).

\section{Discussion}

None of the larvae in the hatchery survived until settling without prophylactic antibacterial treatment during the pelagic stages, indicating a bacterial cause of mortality. In the challenge experiments, $71 \%$ of the bacterial strains that were tested caused a significantly higher rate of larval mortality than was observed in the unchallenged control groups. Of these strains, six (32\%) produced mortality rates that were not statistically distinguishable from that caused by Vibrio pectenicida. 16S rDNA was sequenced from these strains, and a maximum likelihood tree was drawn. Different tree-building methods have different powers to resolve a phylogeny, and simulation studies have demonstrated that $\mathrm{ML}$ is superior to other methods (Hasegawa et al. 1991; Kuhner and Felsenstein 1994; Huelsenbeck 1995). The phylogenetic tree classified the strains into two groups of apparently pathogenic strains: (1) LT13, which resembles the Alteromonas/ Pseudoalteromonas group; (2) strains that resemble the species Vibrio splendidus. Phenotypic characterising by API 20E of these six strains gave the same grouping of strains as the results obtained from the sequencing of the 16S rDNA.

However, some differences in grouping were found when the data from the multidish method was analysed; this could be due to different results found with slow-growing bacteria due to the longer incubation period and/or possible pH differences between the tests. However, we did not investigate this point in any depth. Both groups of suspected pathogens are known. Nicolas et al. (1996) demonstrated that some strains resembling $V$. splendidus are pathogenic to $P$. maximus larvae. $V$. splendidus has been associated with disease outbreaks in a wide range of marine species, including bivalves. Mass mortalities of the related species Argopecten purpuratus larvae in hatcheries in northern Chile have been explained by $V$. splendidus infections (Riquelme et al. 1996b). Jefferies (1982) demonstrated that V. splendidus is also pathogenic to Pacific oyster, Crassostrea gigas, larvae, and Ivanova et al. (1998) isolated representatives of the genus Pseudoalteromonas from the Japanese scallop Platinopecten yessoensis. Recently, Sandaa et al. (2003) confirmed the finding of $V$. splendidus- like and Pseudoalteromonas-like bacteria associated with larvae in the hatchery by means of a molecular fingerprint method, denaturing gradient gel electrophoresis, using LT21 and LT13 as markers, respectively. None of the bacterial strains isolated from the shrimp eggs were able to ferment glucose. Similar results have been obtained from strains isolated from eggs of Atlantic halibut, Hippoglossus hippoglossus (Bergh 1995). Bergh et al. (1994) found that the microflora of halibut larvae was dominated at the outset by non-fermentative bacteria, which were gradually replaced by fermentative strains that were capable of producing acid from a wide range of carbohydrates. These studies indicate that the onset of exogenous feeding is the time of transition between the two kinds of bacterial populations, similar to the shift demonstrated in the intestinal flora of Masu salmon (Oncorhynchus masou) and chum salmon (Oncorhynchus keta) (Yoshimizu et al. 1980). When the digestive tract was activated, the intestinal flora of these species changed from a Pseudomonasdominated flora to one dominated by Aeromonas and Vibrio.

Although the number of strains is limited, our results suggest that the shift occurs when the algae are added and feeding commences. A significantly higher fraction of fermentative strains were found among the bacterial strains present in the untreated larval cultures than from larvae treated with chloramphenicol. Most of the strains examined were sensitive to the diagnostic disc $(\mathrm{O} / 129)$, indicating that they belong to the Vibrio group. While not all vibrios are sensitive to the diagnostic disc (Aoki et al. 1981) and although strains belonging to other groups may also be sensitive (Hansen and Olafsen 1989; Sugita et al. 1994), it is accepted that most vibrios are sensitive to these discs and that only a few strains belonging to other groups are sensitive. In the course of our study we screened Norway's two scallop hatcheries for $V$. pectenicida on the basis of colony morphology (data not shown). This screening process led us to the tentative conclusion that $V$. pectenicida was not present in the hatcheries and that it should therefore be regarded as an exotic pathogen inNorway.

The ARDRA results were inconsistent with respect to the phenotypic characterisations and the $16 \mathrm{~S}$ rDNA sequencing of the pathogens. Grigioni et al. (2000) found a consistency between ARDRA results and sequencing of $16 \mathrm{~s}$ rDNA on strains isolated from Sepia officinalis, and Spangaard et al. (2000) found good consistency between physiological characterisation and characterisation by partial sequencing of $16 \mathrm{~S}$ rDNA of strains isolated from the gut of rainbow trout (Oncorhynchus mykiss). It is 
possible that ARDRA provides better resolution with more closely related strains, as has been shown in a recent study with strains of low diversity isolated from the intestine of halibut, Hippoglossus hippoglossus L. (Jensen et al. 2002). One of the pathogenic strains, LT13, was isolated from the microalga Chaetoceros calcitrans. This finding supports the hypothesis that pathogens can proliferate in algal cultures. Riquelme et al. (1996a) found that Vibrio alginolyticus was the predominant species present in microalgae (Chaetoceros spp. and Isochrysis galbana), swimming larvae, seawater from larval culture tanks and in 50-1m filtered seawater held in the reservoir tank of in a Chilean hatchery of the scallop Argopecten purpuratus. All of the $V$. alginolyticus strains that were isolated, except for one (isolated from swimming larvae), were pathogenic to the scallop larvae. It has been reported that the gastropod mollusc, Clithon retropicus, acquired an increased level of V. parahaemolyticus by feeding on attached microalgae (Kumazawa et al. 1991).

It is not possible, based on morphology alone, to assign the intracellular bacteria of the gut epithelium of the larvae to a specific genus. However, morphologically similar bacteria have been associated with both Rickettsiaceae and Chlamydiaceae (Turnbull 1993; Nylund et al. 1998). Avakyan and Popov (1984) have provided morphological criteria that can be used to separate these two groups of bacteria, including characteristics such as normal anatomy, the formation and structure of altered (abnormal) forms and features of their interaction with host cells. On the basis of these criteria, the intravacuolar bacteria displayed similarities with Chlamydiaceae, while the other intracellular cells showed similarities with some Rickettsiaceae. However, the observations presented in this study are still too meager to base any firm conclusions on the relationships of any of these bacteria. A thorough study of the morphology, development and genetics of these bacteria will be required before the correct taxonomic status of these bacteria can be determined. Intracellular bacteria are common among bivalves, especially Rickettsiceaelike and Chlamydiaceae-like bacteria. While these microorganisms occur in healthy animals without any apparent detrimental effect (Elston 1990), there have been reports of mass mortalities caused by these organisms. Le Gall et al. (1988) reported mass mortalities of Pecten maximus that resulted by bronchial infections caused by Rickettsiales-like organisms, and Leibovitz (1989) established that chlamydiosis is a fatal disease of hatchery-reared larval and postmetamorphic bay scallops (Argopecten irradians). Although prokaryotic infections in marine bivalves molluscs do not appear to promote a response in the host, it has been suggested that heavy infections may reduce the metabolic efficiency and alter the nutritional status of the host (Otto et al. 1979). The bacteria are most commonly found in the epithelial tissues of the gills and digestive gland of the host bivalve mollusc (Elston 1990) and also in the digestive diverticula and kidney of the bay scallop (A. irradians) (Morrison and Shum 1982, 1983). Le Gall et al. (1991) suggested that scallops from Norway appeared to be rickettsia-free based upon histological examination of 20 scallops collected in August 1988. Our study showed that challenge with some of the strains resulted in improved motility compared to the controls. It is possible that some of these strains could be used as probiotics. Strains that possess antagonistic effects on pathogenic Vibrio species have been isolated from scallop (Pecten maximus) larvae (Ruize-Ponte et al. 1999), and similar findings have been reported from Chilean scallops (Argopecten purpuratus) (Riquelme et al. 1996b, 1997; Jorquera et al. 1999) and from studies with Pacific oyster (Crassostrea gigas) larvae (Douillet and Langdon 1993; Gibson et al. 1998; Nakamura et al. 1999), suggesting that beneficial strains may be relatively common in bivalve larval cultures and that their potential should be further investigated.

\section{Conclusions}

The following points summarize the results of the investigation reported here:

- no larvae survived without prophylactic antibacterial treatment, indicating a bacterial causative agent;

- two groups of bacteria produced high rates of mortality in the challenge tests: one cluster of strains was similar to Vibrio splendidus, while the other belonged to the Alteromonas/Pseudoalteromonas group;

- intracellular bacteria probably belonging to the Chlamydiaceae or Rickettsiaceae were found;

- five percent of the bacteria tested in the challenge test caused increased motility of scallop larvae.

\section{Acknowledgements}

This study received financial support from the Norwegian Research Council and the European Commission, contract FAIR GT 97 3926. We thank the personnel of the scallop hatchery for their kind help. 


\section{References}

Aoki T., Kitao T. and Kawano K. 1981. Changes in drug resistance of Vibrio anguillarum in cultured ayu, Plecoglossus altivelis Temminck and Schlegel, in Japan. J. Fish Dis. 4: 223-230.

Avakyan A.A. and Popov V.L. 1984. Rickettsiae and Chlamydiae: comparative electron microscopic studies. Acta Virol. 28: 159173.

Bergh Ø. 1995. Bacteria associated with early life stages of halibut, Hippoglossus hippoglossus L., inhibit growth of a pathogenic Vibrio sp. J. Fish Dis. 18: 31-40.

Bergh Ø., Hansen G.H. and Taxt R.E. 1992. Experimental infection of eggs and yolk sac larvae of halibut, Hippoglossus hippoglossus L. J. Fish Dis. 15: 379-391.

Bergh Ø., Naas K.E. and Harboe T. 1994. Shift in the intestinal microflora of Atlantic halibut (Hippoglossus hippoglossus) larvae during first feeding. Can. J. Fish Aquat. Sci. 51: 1899-1903.

Bergh $\varnothing$. and Strand Ø. 2001. Great scallop, Pecten maximus, research and culture strategies in Norway: a review. Aquacult. Int. 9: 305-318.

Brown C. 1974. A pigment-producing pseudomonad which discolours containers of embryos of a bivalve mollusc. Chesapeake. Sci. 15: 17-21.

Douillet P. and Langdon C. 1993. Effects of marine bacteria on the culture of axenic oyster Crassostrea gigas (Thunberg) larvae. Biol. Bull. 184: 36-51.

Elston R.A. (1990). Rickettsia and Chlamydia of molluscs. In: Mollusc Diseases: Guide for the Shellfish Farmer. University of Washington, Seattle, p. 41.

Elston R.A. and Leibovitz L. 1980. Pathogenesis of experimental vibriosis in larval American oysters, Crassostrea virginica. Can. J. Fish. Aquat. Sci. 37: 964-978.

Felsenstein J. 1993. PHYLIP (Phylogeny Inference Package) Version 3.5c. Distributed by the Author. Department of Genetics, University of Washington, Seattle, USA.

Garland C.D., Nash G.V., Sumner C.E. and McMeekin T.A. 1983. Bacterial pathogens of oyster larvae (Crassostrea gigas) in a Tasmanian hatchery. Aust. J. Mar. Freshwater Res. 34: 483-487.

Gibson L.F., Woodworth J. and George A.M. 1998. Probiotic activity of Aeromonas media on the Pacific oyster, Crassostrea gigas, when challenged with Vibrio tubiashii. Aquaculture 169: 111-120.

Grigoni S., Boucher-Rodoni R., Demarta A., Tonolla M. and Peduzzi R. 2000. Phylogenetic characterisation of bacterial symbionts in the accessory nidamental glands of the sepioid Sepia officinalis (Cephalopoda: Decapoda). Mar. Biol. 136: $217-222$.

Gruffyd L.L.D. and Beaumont A.R. 1970. Determination of the optimum concentration of eggs and spermatozoa for the production of normal larvae in Pecten maximus. Helgoländer Wissenschaft Meerestuners 20: 486-497.

Hansen G.H. and Olafsen J.A. 1989. Bacterial colonization of cod (Gadus morhua L.) and halibut (Hippoglossus hippoglossuss) eggs in marine aquaculture. Appl. Environ. Microbiol. 55: 1435-1446.

Hansen G.H. and Sørheim R. 1991. Improved method for phenotypical characterization of marine bacteria. J. Microbiol. Methods 13: 231-241.

Hasegawa M., Kishino H. and Saitou N. 1991. On the maximum-likelihood method in molecular phylogenetics. J. Mol. Evol. 5: 443-445.

Huelsenbeck J.P. 1995. The robustness of 2 phylogenetic methods - 4-taxon simulation. Mol. Biol. Evol. 5: 843-849.

Ivanova E.P., Kiprianova E.A., Mikhailov V.V., Levanova G.F., Garagulya A.D., Gorshkova N.M., Vysotskii M.V., Nicolau D.V., Yumoto N., Taguchi T. and Yoshikawa S. 1998. Phenotypic diversity of Pseudoalteromonas citrea from different marine habitats and emendation of the description. Int. J. Syst. Bacteriol. 48: 247-265.

Jefferies V.E. 1982. Three Vibrio strains pathogenic to larvae of Crassostrea gigas and Ostrea edulis. Aquaculture 29: 201-226.

Jensen S., Bergh Ø., Enger $\varnothing$. and Hjeltnes B. 2002. Use of PCR-RFLP for genotyping 16S rRNA and characterizing bacteria cultured from halibut fry. Can. J. Microbiol. 48: 379-386.

Jorquera M.A., Riquelme C.E., Loyola L.A. and Muñ oz L.F. 1999. Production of bacterial substances by a marine vibrio isolated from cultures of the scallop Argopecten purpuratus. Aquacult. Int. 7: 433-448.

Karnovsky M.J. 1965. A formaldehyde glutaraldehyde fixative of high osmolarity for use in electron microscopy. J. Cell Biol. 27: 137A (Abstract).

Kuhner M.K. and Felsenstein J. 1994. A simulation comparison of phylogeny algorithms under equal and unequal evolutionary rates. Mol. Biol. Evol. 3: 459-468.

Kumazawa N.H., Nakagaki E., Yonekawa Y., Ikura K. and Morimoto N. 1991. Ecological cycle of thermostable direct hemolysinproducing strains of Vibrio parahaemolyticus in a brackishwater area with special reference to molluscs and attached microalgae. J. Veter. Med. Sci. 532: 263-267.

Lambert C., Nicolas J.L., Cilia V. and Corre S. 1998. Vibrio pectenicida sp. nov., a pathogen of scallop (Pecten maximus) larvae. Int. J. Syst. Bacteriol. 48: 481-487.

Le Gall G., Changot D., Mialhe E. and Grizel H. 1988. Branchial Rickettsiales-like infection associated with a mass mortality of sea scallops Pecten maximus. Dis. Aquat. Organ. 4: 229-232.

Le Gall G., Mialhe E., Chagot D. and Grizel H. 1991. Epizootiological study of rickettsiosis of the Saint-Jacques scallop Pecten maximus. Dis. Aquat. Org. 10: 139-145.

Leibovitz L. 1989. Chlamydiosis: a newly reported serious disease of larval and ostmetamorphic bay scallops, Argopecten irradians (Lamarck). J. Fish Dis. 12: 125-136.

Morrison C. and Shum G. 1982. Chlamydia-like organisms in the digestive diverticula of the bay scallop, Argopecten irradians (Lmk). J. Fish Dis. 5: 173-184. 
Morrison C. and Shum G. 1983. Rickettsias in the kidney of the bay scallop, Argopecten irradians (Lamarck). J. Fish Dis. 6: 537541.

Nakamura A., Takahashi K.G. and Mori K. 1999. Vibriostatic bacteria isolated from rearing seawater of oyster brood stock: potentiality as biocontrol agents for vibriosis in oyster larvae. Fish Pathol. 34(3): 139-144.

Nicolas J.L., Ansquer D. and Cochard J.C. 1992. Isolation and characterisation of a pathogenic bacterium specific to Manila clam, Tapes philipinarum, larvae. Dis. Aquat. Organ. 14: 153-159.

Nicolas J.L., Corre S., Gauthier G., Robert R. and Ansquer D. 1996. Bacterial problems associated with scallop Pecten maximus larval culture. Dis. Aquat. Organ. 27: 67-76.

Nylund A., Kvenseth A.M. and Isdal E. 1998. A morphological study of the epitheliocystis agent in farmed Atlantic salmon. J. Anim. Aquat. Health 10: 43-55.

Otto S.V., Harshbarger J.C. and Chang S.C. 1979. Status of selected unicellular eukaryote pathogens and prevalence and histopathology of inclusions containing obligate prokaryote parasites in commercial bivalve molluscs from Maryland estuaries. Haliotis 8: 285-295.

Riquelme C., Hayashida G., Toranzo A.E., Vilches J. and Chavez P. 1995a. Pathogenicity studies on a Vibrio anguillarum related (VAR) strain causing an epizootic in Argopecten purpuratus larvae cultured in Chile. Dis. Aquat. Organ. 22: 135-141.

Riquelme C., Hayashida G., Vergara N., Vasquez A., Morales Y. and Chavez P. 1995b. Bacteriology of the scallop Argopecten purpuratus (Lamarck, 1819) cultured in Chile. Aquaculture 138: 49-60.

Riquelme C., Toranzo A.E., Barja J.L., Vergara N. and Araya R. 1996a. Association of Aeromonas hydrophila and Vibrio alginolyticus with larval mortalities of scallop (Argopecten purpuratus). J. Invert. Pathol. 67: 213-218.

Riquelme C., Hayashida G., Araya R., Uchida A., Satomi M. and Ishida Y. 1996b. Isolation of a native bacterial strain from the scallop Argopecten purpuratus with inhibitory effects against pathogenic vibrios. J. Shellfish. Res. 15(2): 369-374.

Riquelme C., Araya R., Vergara N., Rojas A., Guaita M. and Candia M. 1997. Potential probiotic strains in the culture of the Chilean scallop Argopecten purpuratus (Lamarck, 1819). Aquaculture 154: 17-26.

Ruiz-Ponte C., Samain J.F., Sa' nchez J.L. and Nicolas J.L. 1999. The benefit of a Roseobacter species on the survival of scallop larvae. Mar. Biotechnol. 8: 52-59.

Sandaa R.-A., Magnesen T., Torkildsen L. and Bergh $\varnothing$. 2003. Characterisation of the bacterial community associated with early stages of great scallop (Pecten maximus), using denaturing gradient gel electrophoresis (DGGE). Syst. Appl. Microbiol. 26: 302-311.

Spangaard B., Huber I., Nielsen J., Appel K.F. and Gram L. 2000. The microflora of rainbow trout intestine: a comparison of traditional and molecular identification. Aquaculture 182: 1-15.

Sugita H., Nakamura T., Tanaka K. and Deguchi Y. 1994. Identification of O/129-sensitive Aeromonas by microplate hybridisation method. Fish. Sci. 60: 351-352.

Sugumar G., Nakai T., Hirata Y., Matsubara D. and Muroga K. 1998. Vibrio spelndidus biovar II as the causative agent of bacillary necrosis of Japanese oyster Crassostrea gigas larvae. Dis. Aquat. Organ. 33: 111-118.

Torkildsen L., Samuelsen O.B., Lunestad B.T. and Bergh Ø. 2000. Minimum inhibitory concentrations of chloramphenicol, florfenicol, trimethoprim/sulfadiazine and flumequine in seawater of bacteria associated with scallops (Pecten maximus) larvae. Aquaculture 185: 1-12.

Tubiash H.S., Chanley P.E. and Leifson E. 1965. Bacillary necrosis, a disease of larval and juvenile bivalve molluscs. J. Bacteriol. 90: 1036-1043.

Turnbull J.F. 1993. Rickettsias and chlamydias. In: Inglish V., Roberts R.J. and Bromage N.R. (eds.), Bacterial Diseases of Fish, Blackwell Science, Oxford, UK, pp. 236-254.

Van de Peer Y., De Rijk P., Wuyts J., Winkelmans T. and De Wachter R. 2000. The European subunit ribosomal RNA database. Nucleic Acids Res. 281: 175-176.

Vaneechoutte M., Rossau R., De Vos P., Gillis M., Janssens D., Paepe N., De Rouck A., Fiers T., Claeys G. and Kersters K. 1992. Rapid identification of bacteria of the Comamonadaceae with amplified ribosomal DNA-restriction analysis (ARDRA). FEMS Microbiol Lett 93: 227-234.

Yoshimizu M., Kimura T. and Sakai M. 1980. Microflora of the embryo and fry of salmonids. Bull. Jpn. Soc. Sci. Fish. 48: 967975. 